\title{
Pengaruh Gaya Kepemimpinan Dan Motivasi Kerja Terhadap Kinerja Karyawan Pada Bank Mandiri KCP Palu Imam Bonjol
}

\author{
Malkan Malkan, ${ }^{1}$ Yusuf Adam ${ }^{2 *}$ Muhammad Syafaat ${ }^{3}$, Syaakir Sofyan ${ }^{4}$ \\ ${ }^{1}$ Jurusan Perbankan Syariah, Fakultas Ekonomi dan Bisnis Islam, IAIN Palu \\ ${ }^{2}$ Jurusan Perbankan Syariah, Fakultas Ekonomi dan Bisnis Islam, IAIN Palu \\ ${ }^{3}$ Jurusan Perbankan Syariah, Fakultas Ekonomi dan Bisnis Islam, IAIN Palu \\ ${ }^{4}$ Jurusan Perbankan Syariah, Fakultas Ekonomi dan Bisnis Islam, IAIN Palu
}

ABSTRAK

Tulisan ini bertujuan untuk mengetahui gaya kepemimpinan dan motivasi kerja berpengaruh secara parsial dan simultan terhadap kinerja karyawan pada Bank Mandiri KCP Palu Imam Bonjol serta dari kedua variabel tersebut manakah yang paling berpengaruh terhadap kinerja karyawan. Populasi dalam penelitian ini adalah seluruh karyawan Bank Mandiri KCP Palu Imam Bonjol yang berjumlah 48 orang. Teknik pengambilan sampel yang digunakan adalah teknik sampel jenuh (saturation sampling), dengan menggunakan rumus sampel jenuh menurut Sugiyono. Teknik pengumpulan data adalah melalui teknik observasi dan kuesioner. Kemudian teknik analisa yang digunakan adalah analisi regresi linear berganda. Hasil olahan statistik yang dibantu dengan program SPSS 21 for windows, menunjukan bahwa gaya kepemimpinan dan motivasi kerja secara simultan berpengaruh terhadap kinerja karyawan pada Bank Mandiri KCP Palu Imam Bonjol. Sedangkan, secara parsial gaya kepemimpinan berpengaruh secara signifikan terhadap kinerja karyawan pada Bank Mandiri KCP Palu Imam Bonjol, sedangkan motivasi kerja berpengaruh namun tidak signifikan. Nilai koefisien determinasi (R2) menunjukan bahwa variabel independen (gaya kepemimpinan dan motivasi kerja) yang diteliti mampu menjelaskan $41,4 \%$ pengaruhnya terhadap variabel dependen (kinerja karyawan pada Bank Mandiri KCP Palu Imam Bonjol), sedangkan sisanya $58,6 \%$ yang dijelaskan oleh variabel independen yang lain yang tidak termaksut dalam penelitian ini.

\section{INFORMASI \\ ARTIKEL}

Katakunci:

Gadai emas, nilai taksir, biaya ijarah, keputusan nasabah
1. PENDAHULUAN

Dalam peradaban manusia
sekarang ini segala aspek kehidupan

e-ISSN: 2686-6625 


\section{Jurnal Ilmu Perbankan dan Keuangan Syariah Vol. 1 No. 2 Tahun 2020}

tidak lepas dari berorganisasi. Berorganisasi adalah kodrat alamiah manusia yang pada hakikatnya manusia adalah makhluk sosial, ia tidak akan mampu hidup tanpa manusia lain yang ada disekitarnya. Manusia sendiri memerlukan komunitas untuk berinteraksi guna memenuhi hidupnya. Manusia sebagai makhluk individual yang memiliki dua misi di dunia yaitu misis dimensi vertikal berupa ketundukan pada sang khalik dan misi dimensi horizontal berupa hubungan antara manusia dan alam lingkungan. Dimensi horizontallah yang mencerminkan dimana manusia menjadi kontrol sosial bagi dirinya dengan lingkungan masyarkatnya. Maka manusia berperaan dalam sebuah gerakan yang disebut dengan organisasi. Ketika manusia berorganisasi maka ia akan berinteraksi, dan masuk menjadi bagian dalam organisasi tempatnya bekerja yang merupakan wadah untuk menyelaraskan dan menyeimbangkan misi berjuang untuk memakmurkan hidupnya. ${ }^{1}$

Dalam

organisasi, mencapai setiap sumber daya untuk mencapainya. Sumber daya itu antara lain sumber daya alam, sumber daya finansial, sumber daya ilmu dan pengetahuan teknolgi, serta sumber daya manusia. Di antara sumber daya tersebut, sumber daya yang terpenting ialah sumber daya manusia. ${ }^{2}$

${ }^{1}$ Veithzal Rivai, dkk, Pemimpin dan Gaya Kepemimpinan dalam Organisasi (Jakarta: Rajawali Pers, 2014), 57.

${ }^{2}$ Bryan Johannes Tampi, "Pengaruh Gaya Gaya Kepemimpinan dan Motivasi Terhadap Kinerja Karyawan pada PT. Bank Negara Indonesia, TBK
Sumber daya manusia merupakan instrumen sentral dalam organisasi

maupun perusahaan. Agar aktivitas manajemen berjalan dengan baik, perusahaan harus memiliki karyawan yang berpengetahuan dan berketrampilan tinggi serta usaha untuk mengelola perusahaan seoptimal mungkin sehingga kinerja karyawan meningkat.

Menurut Budi Setiyawan dan Waridin kinerja karyawan merupakan hasil atauprestasi kerja karyawan yang dinilai dari segi kualitas maupun kuantitas berdasarkan standar kerja yang ditentukan oleh pihak organisasi. ${ }^{3}$ Kinerja yang baik adalah kinerja yang optimal, yaitu kinerja yang sesuai standar organisasi dan mendukung tercapainya tujuan organisasi. Organisasi yang baik adalah organisasi yang berusaha meningkatkan kemampuan sumber daya manusianya, karena hal tersebut merupakan faktor kunci untuk meningkatkan kinerja karyawan. ${ }^{4}$

Untuk mencapai tujuan organisasi, tentunya karyawan dituntut untuk memaksimalkan kinerja yang dia

(Regional Sales Manado), http://www.academia.edu, diakses 6 Januari 2019.

3 Nurdin, N. (2018). Institutional Arrangements in E-Government Implementation and Use: A Case Study From Indonesian Local Government. International Journal of Electronic Government Research (IJEGR), 14(2), 44-63. https://doi.org/10.4018/ijegr.2018040104

${ }^{4}$ Regina Aditya Reza, "Pengaruh Gaya Gaya Kepemimpinan, Motivasi dan Disiplin Kerja Terhadap Kinerja Karyawan PT. Sinar Santosa Perkasa Banjarnegara”. Skripsi (Fakultas Ekonomi, Universitas Diponegoro, 2010), http://eprints.undip.ac.id, diakses 8 Januari 2019. 


\section{Jurnal Ilmu Perbankan dan Keuangan Syariah Vol. 1 No. 2 Tahun 2020}

miliki. Kinerja merupakan hasil pekerjaan yang mempunyai hubungan kuat dengan tujuan strategis organisasi, kepuasan konsumen, dan memberikan kontribusi pada ekonomi. Dengan demikian, kinerja adalah tentang melakukan pekerjaan dan hasil yang di caapai dari pekerjaan tersebut. Kinerja tentang apa yang dikerjakan dan bagaimana cara mengerjakannya. ${ }^{5}$

Terdapat faktor-faktor negatif yang dapat menurunkan kinerja karyawan, diantaranya adalah menurunnya keinginan karyawan umtuk mencpai prestasi kerja, kurangnya ketepatan waktu dalam menyelesaikan pekerjaan sehingga kurang menaati peraturan, pengaruh yang berasal dari lingkungannya, teman sekerja yang juga menurun semangatnya dan tidak adanya contoh yang harus dijadikan acuan dalam pencapaian prestasi kerja yang baik. Dalam hal tersebut peran seorang pemimpin menjadi juru kunci dalam membangun semangat bawahannya bekerja untuk mencapai tujuan perusahaan. Semua itu merupakan beberapa sebab menurunnya kinerja karyawan dalam bekerja. ${ }^{6}$

Setiap pemimpin memiliki keiginan untuk membangun dan mengembangkan mereka yang dipimpinnya sehingga tumbuh banyak pemimpin dalam kelompoknya. Keberhasilan seorang pemimpin sangat tergantung dari kemampuannya untuk membangun orang-orang disekitarnya, karena keberhasilan sebuah organisasi sangat tergantung pada potensi sumber

${ }^{5}$ Wibowo, Manajemen Kinerja (Jakarta: Rajawali Pers, 2012), 7.

6Ibid, 2. daya manusia dalam organisasi tersebut. Jika sebuah organisasi atau masyarakat mempunyai banyak anggota dengan kualitas pemimpin, organisasi atau bangsa tersebut akan berkembang menjadi kuat. ${ }^{7}$

Peran pemimpin sangat penting dalam sebuah organisasi. Bisa dilihat pada salah satu Badan Usaha Milik Negara (BUMN) yaitu PT Bank Mandiri KCP Palu Imam Bonjol, dimana seorang pemimpin berperan untuk mengarahkan dan memotivasi karyawannya demi mencapai tujuan dan target yang telah ditetapkan. Karyawan memiliki target yang harus di capai agar bisa berkontribusi untuk mencapai tujuan organisasi.

Fenomena pada Bank Mandiri KCP Palu Imam Bonjol dalam jangka waktu dua sampai tiga tahun akan dilakukan pergantian pimpinan yang berasal dari kebijakan pimpinan (Area Head) untuk mengatur penenpatannya, dimana setiap pemimpin memiliki gaya Gaya Kepemimpinan yang berbeda. Dimana setiap gaya Gaya Kepemimpinan memiliki dampak positif maupun negative atas kinerja karyawan. Aspek motivasi kerja karyawan juga menjadi aspek penting dalam kinerja karyawan dimana dalam jaman globalisasi sekarang ini tentunya kebutuhan setiap karyawan akan semakin bertambah seiring perkembangan jaman.

Dengan melihat dan memperhatikan uraian-uraian tersebut diatas, dan berdasarkan pengalaman observasi di Bank Mandiri KCP Palu Imam Bonjol, penulis tertarik mengukur

7Veithzal Rivai, dkk, Pemimpin, 1. 


\section{Jurnal Ilmu Perbankan dan Keuangan Syariah Vol. 1 No. 2 Tahun 2020}

sejauh mana penagaruh Gaya Kepemimpinan dan motivasi untuk meningkatkan kinerja karyaawan.

\section{TINJAUAN PUSTAKA}

\section{a. Pengertian Kepemimpinan}

Apabila berkumpul tiga orang atau lebih kemudian salah seorang diantara mereka "mengajak" temantemannya untuk melakukan sesuatu (Apakah: menonton sinetron, film, bermain sepak bola, dan lain-lain). Pada pengertian yang sederhana orang tersebut telah melakukan "kegiatan memimpin", karena ada unsur "mengajak" dan mengoordinasi, ada teman dan kegiatan dan sasaran. ${ }^{8}$

Kepemimpinan adalah suatu perilaku dengan tujuan tertentu untuk mempengaruhi aktivitas para anggota kelompok untuk mencapai tujuan bersama yang dirancang untuk memberikan manfaat individu dan organisasi, sehingga dalam suatu organisasi kepemimpinan merupakan faktor yang sangat penting dalam menentukan pencapaian tujuan yang telah ditetapkan oleh organisasi. ${ }^{9}$

Ada beberapa pendapat yang dikemukakan para ahli mengenai devisi dari kepemimpinan, yaitu:

8 Nurdin, N., Stockdale, R., \& Scheepers, H. (2014). Coordination and Cooperation in E-Government: An Indonesian Local E-Government Case The Electronic Journal of Information Systems in developing Countries, 61(3), 1-21.

${ }^{9}$ Veithzal Rivai, dkk, Pemimpin dan Kepemimpinan dalam Organisasi (Jakarta: Rajawali Pers), 3.
1) Ro bbins dan Jugde menyatakan bahwa kepemimpinan adalah kemampuan untuk mempengaruhi suatu kelompok menuju pencapaian sebuah visi atau serangkaian tujuan. ${ }^{10}$

2) Fiedle menyatakan kepemimpinan pada dasarnya merupakan pola hubungan antara individu-individu yang menggunakan wewenang dan pengaruhnya terhadap kelompok orang agar bekerja bersama-sama untuk mencapai tujuan. ${ }^{11}$

3) Menurut Susili Martoyo bahwa kepemimpinan adalah keseluruhan aktivitas dalam rangka mempengaruhi orang-orang agar mau bekerja sama untuk mencapai suatu tujuan yang memang di inginkan bersama. ${ }^{12}$

Berdasarkan devinisi di atas, dapat disimpulakan bahwa kepemimpinan adalah kemampuan seseorang dalam mempengaruhi aktivitas suatu kelompok orang agar mau bekerja sama untuk mencapai suatu tujuan yang telah ditetapkan bersama. ${ }^{13}$

b. Teori Kepemimpinan

10Wibowo, Perilaku Dalam Organisasi (Jakarta: PT RajaGrafindo Persada, 2016), 280.

${ }^{11}$ Veithzal Rivai dkk, Pemimpin, 3.

12Susilo Martoyo, Manjemen Sumber Daya Manusia (Yogyakarta : BPFE-Yogyakarta, 2000), 176.

13 Nurdin, N., Stockdale, R., \& Scheepers, H. (2012). Internal Organizational Factors Influencing Sustainable Implementation of Information Systems : Experiences from a Local Government in Indonesia Australasian Conference on Information Systems (ACIS) 2012, Deakin University, Geelong, Victoria, Australia. http://dro.deakin.edu.au/view/DU:30049058 


\section{Jurnal Ilmu Perbankan dan Keuangan Syariah Vol. 1 No. 2 Tahun 2020}

Teori

kepemimpinan membicarakan bagaimana seseorang menjadi pemimpin, atau bagaimana timbulnya seorang pemimpin. Ada beberapa teori tentang kepemimpinan. Menurut Adam Ibrahim Indrawijaya "pada dasarnya ada dua teori kepemimpinan, yaitu teori sifat (traits theory) dan teori situasional (situational theory)", yaitu; teori kelebihan, teori sifat, teori keturunan, teori karismatik, teori bakat, dan teori sosial.

Untuk mendapatkan gambaran yang lebih jelas mengenai teori-teori kepemimpinan, maka berikut akan diuraikan beberpa teori kepemimpinan.

1) Teori Kelebihan

Beranggapan bahwa seseorang akan menjadi pemimpin apabila ia memiliki kelebihan dari pada pengikutnya. Pada dasarnya kelebihan yang harus dimiliki oleh seorang pemimpin mencakup tiga hal, pertama, kelebihan ratio; ialah kelebihan menggunakan pikiran, kelebihan dalam pengetahuan tentang hakikat tujuan dari organisasi, dan kelebihan dalam memiliki pengetahuan tentang cara-cara menggerakan organisasi, serta dalam pengambilan keputusan yang cepat dan tepat, kedua, kelebihan rohaniah; berarti seorang pemimpin harus mampu menunjukkan keluruhan budi pekertinya kepada para bawahan. Seorang pemimpin harus mempunyai moral yang tinggi karena pada dasarnya pemimpin merupakan panutan para pengikutnya. Segala tindakan, perbuatan, sikap dan ucapan hendaknya menjadi suri teladan bagi para pengikutnya, ketiga, kelebihan badaniah; seorang pemimpin hendaknya memiliki kesahatan badaniah yang lebih dari pada pengikutnya sehingga memungkinkannya untuk bertindak dengan cepat. Akan tetapi, masalah kelebihan badaniah ini bukan merupakan faktor pokok.

2) Teori Sifat

Pada dasarnya sama dengan teori kelebihan. Teori ini menyatakan bahwa seseorang dapat menjadi pemimpin yang baik apa bila memiliki sifat-sifat yang lebih dari pada yang dipimpin. Di samping memiliki kelebihan pada ratio, rohaniah, dan badaniah, seorang pemimpin hendaknya memiliki sifatsifat yang positif, misalnya; adil, suka melindungi, penuh percaya diri, penuh inisiatif, mempunyai daya tarik, energik, persuasif, komunikatif dan kreatif. Menurut Miftah Thoha, sesungguhnya tidak ada korelasi sebab akibat antara sifat dan keberhasilan manajer, pendapatnya itu merujuk pada hasil penelitian Keith Davisyang menyimpulkan ada empat sifat umum yang berpengaruh terhadap keberhasilan kepemimpinan organisasi, yaitu: (1) Kecerdasan (di atas disebutkan kelebihan ratio). Hasil penelitian pada umumnya membuktikan bahwa pemimpin mempunyai tingkat kecerdasan yang lebih tinggi dibandingakan dengan yang dipimpin. Namun demikian, pemimpin tidak bisa melampaui terlalu banyak dari kecerdasan pengikutnya;

Kedewasaan dan keleluasaan hubungan sosial, para pemimpin cenderung menjadi matang dan mempunyai emosi yang stabil, serta mempunyai perhatian yang luas terhadap aktivitas-aktivitas sosial. Dia mempunyai keinginan menghargai dan dihargai; (3) Motivasi dan dorongan berprestasi, para 


\section{Jurnal Ilmu Perbankan dan Keuangan Syariah Vol. 1 No. 2 Tahun 2020}

pemimpin secara relatif mempunyai dorongan motivasi yang kuat untuk berprestasi. Mereka berusaha mendapatkan penghargaan yang intrinsik dibandingkan dari yang ekstrinsik; (4) Sifat-sifat hubungan kemanusiaan, para pemimpin yang berhasil mau mengakui harga diri dan kehormatan para pengikutnya dan mampu berpihak kepadanya, dalam istilah penelitian Universitas Ohio pemimpin itu mempunyai perhatian, dan kalau mengikuti istilah penemuan Michigan, pemimpin itu berorientasi pada karyawan bukannya berorientasi pada produksi. Hal serupa juga diungkapkan oleh Adam Ibrahim Indrawijaya dalam bukunya Perilaku Organisasi.

3) Teori Keturunan

Menurut Wursanto yang menyatakan bahwa seseorang mendapat menjadi pemimpin karena keturunan atau warisan. Karena orang tuanya seorang pemimpin, maka anaknya otomatis akan menjadi pemimpin mengantikan orang tuanya, seolah-olah seseorang menjadi pemimpin karena ditakdirkan.

4) Teori karismatik

$$
\text { Yang menyatakan bahwa }
$$
seseorang menjdi pemimpin karena mempunyai karisma (pengaruh) yang sangat besar. Karisma itu diperoleh dari kekuatan Yang Maha Kuasa. Dalam hal ini, ada suatu kepercayaan bahwa orang itu adalah pancaran Zat Tunggal, sehingga dianggap mempunyai kekuatan gaib (spranatural power). Pemimpin yang bertipe karismatik biasanya memiliki daya tarik, kewibawaan dan pengaruh yang yang sangat besar.

\section{5) Teori Bakat}

Yang disebut juga teori ekologis, menyatakan bahwa pemimpin itu lahir karena bakatnya. Ia menjadi pemimpin karena mempunyai bakat untuk menjadi pemimpin. Bakat kepemimpinan itu harus dikembangkan, misalnya dengan memberi kesempatan orang tersebut untuk menduduki suatu jabatan.

6) Teori Sosial

Beranggapan bahwa pada dasarnya setiap orang dapat menjadi pemimpin. Setiap orang mempunyai bakat untuk menjadi pemimpin asal dia diberi kesempatan. Setiap orang dapat dididik menjadi pemimpin karena masalah kepemimpinan dapat dipelajari, baik melalui pendidikan formal maupun melalui pengalaman praktik.

c. Pemimpin Menurut Pandangan Islam

1). Pengertian Kepemimpinan Islam

Imamah atau kepemimpinan Islam adalah konsep yang tercantum dalam Al-Qur'an dan As-Sunnah, yang meliputi kehidupan Manusia dari pribadi, berdua, keluarga bahkan sampai umat manusia atau kelompok. Konsep ini mencakup baik cara-cara memimpin maupun dipimpin demi terlaksananya ajaran Islam untuk menjamin kehidupan yang lebih baik di dunia dan akhirat sebagai tujuannya. Kepemimpinan Islam, sudah merupakan fitrah bagi setiap manusia yang sekaligus memotivasi kepemimpinan yang Islami. ${ }^{14}$ Manusia diamanahi Allah untuk menjadi khalifah Allah (wakil Allah) di muka bumi, yang disampaikan dalam firman Allah Swt

\footnotetext{
14Veithzal Rivai, dkk, Pemimpin, 27.
} 


\section{Jurnal Ilmu Perbankan dan Keuangan Syariah Vol. 1 No. 2 Tahun 2020}

dalam Surah Al-Baqarah [2] : 30 yang terjemahannya:

"Ingatlah ketika Tuhanmu berfirman kepada Para Malaikat: "Sesungguhnya aku hendak menjadikan seorang khalifah di muka bumi." mereka berkata: "Mengapa Engkau hendak menjadikan (khalifah) di bumi itu orang yang akan membuat kerusakan padanya dan menumpahkan darah, Padahal Kami Senantiasa bertasbih dengan memuji Engkau dan mensucikan Engkau?"Tuhan berfirman: "Sesungguhnya aku mengetahui apa yang tidak kamu ketahui."15

Sebagaimana dikemukakan di atas. Mustafa al-Maraghi, mengatakan khalifah adalah wakil Tuhan di muka bumi (khalifah fil ardli). Rasyid Ridla alManar, menyatakan khalifah adalah sosok manusia yang dibekali kelebihan akal, pikiran dan pengetahuan untuk mengatur. Istilah atau perkataan khalifah ini, mulai popular digunakan setelah Rasulullah Saw. wafat. Dalam istilah yang lain, kepemim[inan juga terkandung dalam pengertian "Imam", yang berarti pemuka agama dan pemimpin spiritual yang diteladani dan dilaksanakan fatwanya. ${ }^{16}$

Konsep amanah yang diberikan kepada manusia sebagai khalifah fil ardli menempati posisi sentral dalam kepemimpinan Islam. Logisnya bila konsep amanah kekhalifahan yang diberikan kepada manusia menuntut terjalinnya hubungan atau interaksi

${ }^{15}$ Kementrian Agama RI, Al-Qur'an dan Terjemahan, (Jakarta: Alhuda ), 7.

16Veithzal Rivai, dkk, Pemimpin, 10. yang baik-baiknya antara manusia dengan pemberi amanah (Allah), yaitu: (1) mengerjakan semua perintah Allah, (2) menjauhi semua larangan-Nya, (3) ridha (ikhlas) menerima semua hukumhukum atau ketentuan-Nya. Selain hubungan dengan pemberi amanah (Allah), juga membangun hubungan baik dengan sesama manusia serta lingkungan yang diamanahkan kepadanya.

Tuntutannya,

diperlukan kemampuan memimpin atau mengatur hubungna vertikal manusia dengan Sang Pemberi (Allah) amanah dan interaksi horizontal dengan sesamanya.

Jika kita memperhatikan teoriteori fungsi dan peran seorang pemimpin yang digagas dan dilontarkan oleh pemikir-pemikir dari dunia Barat, maka kita akan hanya menemukanbahwa aspek kepemimpinan itu sebagai konsep interaksi, relasi, proses otoritas maupun kegiatan mempengaruhi, mengarahkan dan mengoordinasikan secara horizontal semata. Konsep Islam, kepemimpinan sebagai sebuah konsep interaksi, relasi, proses otoritas, kegiatan mempengaruhi, mengarahkan, dan mengoordinasi baik secra horizontal maupun vertikal. Menurut Aunur Rahim, dkk., dalam teori manajemen, fungsi pemimpin sebagai perencana dan pengambil keputusan (planning and decision maker), pengorganisasian

(organization), kepemimpinan dan motivasi (leading and motivation), pengawasan (controlling), dan lain-lain. ${ }^{17}$

Berdasarkan uraian di atas, dapat ditegaskan bahwa, kepemimpinan Islam

\footnotetext{
${ }^{17}$ Veithzal Rivai, dkk, Pemimpin, 29.
}

e-ISSN: 2686-6625 


\section{Jurnal Ilmu Perbankan dan Keuangan Syariah Vol. 1 No. 2 Tahun 2020}

adalah suatu proses atau kemampuan orang lan untuk mengarahkan dan memotivasi tingkah laku orang lain, serta ada usaha kerja sama sesuai dengan Al-Qur'an dan Hadis untuk mencapai tujuan yang diinginkan bersama.

\section{Gaya Kepemimpinan}

Setiap pemimpin pada dasarnya memiliki perilaku yang berbeda dalam memimpin para pengikutnya. Perilaku pemimipin ini secara singkat disebut gaya kepemimpinan (leadership stile). ${ }^{18}$ Gaya kepemimpinan merupakan suatu cara pemimpin untuk mengetahui bawahannya yang dinyatakan dalam bentuk pola tingkah laku atau kepribadian.

Menurut Miftah Toha gaya kepemimpinan merupakan norma perilaku yang digunakan seseorang pada saat orang tersebut mencoba memengaruhi perilaku orang lain. Oleh karenanya usaha menyelaraskan presepsi diantara yang akan memengaruhi dengan orang yang perilakunya akan dipengaruhi menjadi amat penting. Duncan menyebutkan ada tiga gaya kepemimpinan, yaitu: otoriter, demokrasi, dan gaya bebas (the laisser faire) .19

1) Otoriter (Authoritarian Leadership) Seperti diketahui bahwa kekuasaan otoriter gaya kepemimpinan

18 Nurdin, N., \& Yusuf, K. (2020). Knowledge management lifecycle in Islamic bank: the case of syariah banks in Indonesia. International Journal of Knowledge Management Studies, 11(1), 59-80. https://doi.org/10.1504/ijkms.2020.105073 berdasarkan pada kekuasaan yang mutlak dan penuh, dimana seorang pemimpin yang memusatkan segala keputusan dan kebijakan yang diambil dari dirinya sendiri secara penuh. Segala pembagian tugas dan tanggung jawab dipegang oleh si pemimpin yang otoriter tersebut, sedang para bawahan hanya melaksanakan tugas yang telah diberikan.

Menurut Fandi Tjiptono dan Anastasia Diana kepemimpinan otoriter disebut juga kepemimpinan dictator atau direktif. Orang yang menganut pendekatan ini mengambil keputusan tanpa berkonsultasi dengan para karyawan yang harus melaksanakannya atau karyawan yang dipengaruhi keputusan tersebut. Sedangkan menurut Wursanto kepemimpinan otoriter adalah kepemiminan yang mendasarkan pada suatu kekuasaan atau kekuatan yang melekat pada dirinya. Kepemimpinan otoriter dapat dilihat dari ciri-cirinya antara lain: (a) mengandalkan kepada kekuatan atau kekuasaan yang melekat pada dirinya, (b) menganggap dirinya paling berkuasa, (c) menganggap dirinya paling mengetahui segala persoalan, orang lain dianggap tidak tahu, (d) keputusan-keputusan yang diambil secara sepihak, tidak mengenal kompromi, sehingga ia tidak mau menerima saran dari bawahan, bahkan ia tidak member kesempatan kepada bawahan untuk member saran, pendapat atau ide, (e) keras dalam menghadapi prinsip, (f) jauh dari bawahan, (g) lebih menyukai bawahan yang bersikap abs (asal bapak senang), (h) perintah-perintah diberikan secara paksa, (i) pengawasan dilakukan secara

${ }^{19}$ Ibid., 265. 


\section{Jurnal Ilmu Perbankan dan Keuangan Syariah Vol. 1 No. 2 Tahun 2020}

keras agar perintah benar-benar dilaksanakan.

2) Kepemimpinan

Demokrasi

(Democratic Leadership)

Yang dimaksut dengan gaya kepemimpinan demokrasi adalah gaya pemimpin yang memberikan wewenang secara luas kepada para bawahan. Setiap ada permasalahan selalu mengikutsertakan bawahan sebagai suatu tim yang utuh. Dalam gaya kepemimpinan demokrasi pemimpin memberikan banyak informasi tentang tugas serta tanggung jawab para bawahannya. Dalam gaya ini, besar peluang untuk melakukan pengembangan diri. Sehingga setiap orang yang dipimpin memiliki motivasi diri untuk berkembang.

Gaya pemimpin demokrasi yang seperti ini misalnya saja si pemimpin memberikan kebebasan dan keleluasaan kepada para bawahan dan pengikutnya untuk mengemukakan pendapatnya saran dan kritikannya dan selalu berpegang pada nilai-nilai demokrasi pada umumnya. ${ }^{20}$

Menurut Fandi Tjiptono dan Anastasia Diana gaya atau tipe kepemimpinan ini dikenal pula dengan istilah kepemimpinan konsultatif atau consensus. Orang yang menganut pendekatan ini melibatkan para karyawan yang melaksanakan keputusan dalam proses pembuatannya, walaupun yang membuat keputusan akhir adalah pemimpin, setelah menerima masukan dan rekomendasi dari anggota tim. Sedangkan menurut Adam Ibrahim Indrawijaya "Gaya kepemimpinan Demokrasi pada

${ }^{20}$ Ibid., 136. umumnya berasumsi bahwa pendapat orang banyak lebih baik dari pendapatnya sendiri dan adanya partisipasi akan menimbulkan tanggung jawab bagi pelaksananya".

3) Kepemimpinan Bebas (laisez Faire Leadership)

Dalam kepemimpinan jenis ini, sang pemimpin biasanya menunjukan suatu gaya dan perilaku yang pasif dan juga sering kali menghindari dirinya dari tanggung jawab. Dalam praktiknya, si pemimpin hanya menyerahkan dan menyediakan instrument dan sumbersumber yang diperlukan oleh anak buahnya untuk melaksanakan suatu pekerjaaan untuk mencapai tujuan yang ditetapkan pimpinan. Pimpinan yang memiliki gaya ini memang berada diantara anak buahnya, akan tetapi ia tidak memberikan motivasi, pengarahan dan petunjuk, dan segala pekerjaan di serahkan kepada anak buahnya.

Gaya kepemimpinan yang lebih banyak menekan pada keputusan kelompok. Menurut Adam Ibrahim Indrawijaya dalam gaya ini seorang pemimpin akan menyerahkan keputusan kepada keinginan kelompok, apa yang baik menurut kelompok itulah yang menjadi keputusan. Pelaksanaannya pun tergantung kepada kemauan kelompok. Pada umumnya tipe laissez faire dijalankan oleh pemimpin yang tidak mempunyai keahlian teknis. Tipe laissez faire mempunyai ciri-ciri antara lain: (a) memberikan kebebasan sepenuhnya kepada bawahan untuk melakukan tindakan yang dianggap perlu sesuai dengan bidang tugas masing-masing, (b) pimpinan tidak ikut berpatisipasi aktif dalam kegiatan kelompok, (c) semua 


\section{Jurnal Ilmu Perbankan dan Keuangan Syariah Vol. 1 No. 2 Tahun 2020}

pekerjaan dan tanggung jawab dilimpahkan kepada bawahan, (d) tidak mampu melakukan koordinasi dan pengawasan yang baik, (e) tidak mempunyai wibawa sehingga ia tidak ditakuti apalagi disegani oleh bawahan, (f) secara praktis pemimpin tidak menjalankan kepemimpinan, ia hanya merupakan simbol belaka.

\section{Motivasi Kerja}

Pada awalnya, motivasi seseorang untuk melakukan kegiatan muncul karena merasakan perlunya untuk memenuhi kebutuhan. Apabila kebutuhannya telah terpenuhi, maka motivasinya akan menurun. Kemudian berkembang pemikiran bahwa motivasi juga diperlukan untuk mencapai tujuan tertentu. Namun apabila tujuan telah tercapai, biasanya motivasi juga menurun. Oleh karena itu, motivasi dapat dikembangkan apabila timbul kebutuhan maupun tujuan baru. Apabila pemenuhan merupakan kebutuhan manusia, maka tujuan dapat menjadi kepentingan manusia maupun organisasi.

Dengan demikian terdapat kepentingan bersama antara manusia sebagai pekerja dengan organisasi. Pekerja di suatau sisi memerlukan pekerjaan mengharapkan kompensasi untuk pemenuhan kebutuhannya dan di sisi lain untuk mencapai tujuan pribadinya untuk mewujudkan prestasi kerjanya. Kinerja dari semua pekerja untuk mencapai tujuan organisasi.

Apabila pekerja mempunyai motivasi untuk mencapai tujuan pribadinya, maka mereka harus meningkatkan kinerja. Meningkatkan kinerja pekerja akan meningkatkan pula kinerja organisasi. Dengan demikian, meningkatkannya motivasi pekerja akan meningkatkan kinerja individu, kelompok maupun organisasi.

Untuk menginspirasi orang untuk bekerja, sebagai individu maupun kelompok dengan cara yang dapat menghasilkan hasil terbaik, kita perlu membuka kekuatan motivasional pribadi mereka sendiri. Seni untuk memotivasi orang dimulai dengan mempelajari bagaimana mempengaruhi perilaku individu. Apabila telah memahami, kita mungkin akan mendapatkan manfaat yang diinginkan baik organisasi maupun pekerjanya. ${ }^{21}$

a. Pengertian motivasi

Terdapat banyak pengertian tentang motivasi. Diantranya adalah Robert Heller yang menyatakan bahwa motivasi adalah keinginan untuk bertindak. Ada pendapat bahwa motivasi harus diinjeksi dari luar, tetapi sekarang semakin dipahami bahwa setiap orang termotivasi oleh beberapa kekuatan yang berbeda. Dipekerjaan kita perlu mempengaruhi bawahan untuk menyelaraskan motivasinya dengan kebutuhan organisasi. ${ }^{22}$

Newstro menyatakan motivasi kerja adalah hasil dari kumpulan kekuatan internal dan eksternal yang menyebabkan pekerja memilih jalan bertindak yang sesuai dan menggunakan perilaku tertentu. Idealnya, perilaku ini akan diarahkan pada pencapaian tujuan organisasi. ${ }^{23}$

\footnotetext{
${ }^{21}$ Wibowo, Manajemen Kinerja (Jakarta:

Rajawali Pers, 2012), 378.

${ }^{22}$ Ibit., 378.

23Wibowo, Perilaku Dalam Organisasi (Jakarta: Rajawali Pers, 2016), 110.
}

e-ISSN: 2686-6625 


\section{Jurnal Ilmu Perbankan dan Keuangan Syariah Vol. 1 No. 2 Tahun 2020}

Motivasi merupakan proses psikologis yang membangkitkan dan mengarahkan perilaku pada pencapaian tujuan atau goal-directed behavior. Manajer perlu memahami proses psikologis ini apabila mereka ingin berhasil membina pekerja menuju pada penyelesaian sasaran organisasi.

Dari pendapat-pendapat di atas dapat disimpulkan bahwa motivasi merupakan proses psikologis pada seseorang untuk membangkitkan kekuatan dalam melakukan pencapaian tujuan (goal).

b. Faktor-faktor yang mempengaruhi Motivasi

Maslow mengemukakan teori motivasi yang dinamakan Maslow's Need Hierarchy Theory atau Terori Hierarki Kebutuhan dari Maslow. Hierarki kebutuhan mengikuti teori jamak yakni seseorang berprilaku/bekerja, karena adanya dorongan untuk memenuhi bermacammacam kebutuhan. Maslow berpendapat, kebutuhan yang diinginkan seorang itu berjenjang. Artinya jika kebutuhan yang pertama terpenuhi maka kebutuhan kedua menjadi utama. Selanjutnya jika kebutuhan kedua terpenuhi maka kebutuhan ketiga akan menjadi utama dan seterusnya sampai tingkat kebutuhan yang kelima. ${ }^{24}$

Kebutuhan dapat didefinisikan sebagai suatu kesenjangan atau pertentangan yang dialami antara suatu kenyataan dengan dorongan yang ada dalam diri. Apabila pegawai kebutuhannya tidak terpenuhi maka

${ }^{24}$ Malayu Hasibuan, Manajemen Sumber Daya Manusia, (Edisi Revisi. Jakarta : Bumi aksara, 2012), 154. pegawai tersebut akan menunjukan perilaku kecewa. Sebaliknya, jika kebutuhannya terpenuhi maka pegawai tersebut akan memperlihatkan perilaku gembira sebagai manifestasi dari rasa puasnya. Abraham aslow mengemukakan bahwa hierarki kebutuhan manusia adalah sebagai berikut: 25

1) Kebutuhan fisiologis, yaitu kebutuhan untuk makan, minum, perlindungan fisik, bernapas, seksual. Kebutuhan ini merupakan kebuthan tingkat rendah atau disebut pula sebagai kebutuhan yang paling dasar.

2) Kebutuhan rasa aman, yaitu kebutuhan akan perlindungan dari ancaman, bahaya, pertentangan, dan lingkungan hidup.

3) Kebutuhan untuk merasa memiliki, yaitu kebutuhan untuk diterima oleh kelompok, berafiliasi, berinteraksi, dan kebutuhan untuk mencintai serta dicinta.

4) Kebutuhan akan harga diri, yaitu kebutuhan untuk dihormati, dan dihargai oleh orang lain.

5) Kebutuhan untuk mengaktualisasikan diri, yaitu kebutuhan untuk menggunakan kemampuan, skill, dan potensi. Kebutuhan untuk berpendapat dengan mengemukakan ide-ide memberi penilaian dan kritik terhadap sesuatu.

\section{Pandangan Islam Tentang Motivasi}

Sejalan dengan teori yang berkembang, komunikasi dan motivasi adalah kunci keberhasilan sebuah proses

${ }^{25}$ A.Anwar Prabu Mangkunegara, Manajemen Sumber Daya Manusia Perusahaan (Bandung: PT. Remaja Rosdakarya, 2011), 95. 


\section{Jurnal Ilmu Perbankan dan Keuangan Syariah Vol. 1 No. 2 Tahun 2020}

kepemimpinan dalam Islam. Salah satu yan paling menetukan kepemimpinan Islam adalah komunikasi dan motivasi.Setidaknya ada beberapa hal yang menjadikan komunikasi efektif ialah qaulan karima.

Menurut Hamka yang dikutip Rivai, mengartikannya dengan perkataan yang pantas, kata-kata yang mulia lebih lanjut Hamka adalah katakata yang membesarkan hati dan memberikan motivasi, yang menimbulkan kegembiraan kembali pada cahaya mata yang mulai kuyu karena tekanan umur, diiringi dengan kasih mesra, yang datang dari lubuk hati yang tulus dan ikhlas. Dalam Islam juga dikenal istilah qaulan baligha, yakni perkataan yang disesuaikan dengan bahasa komunikasinya.Hal ini senada dengan keberadaan Rasul yang di utus sesuai dengan bahasa kaumnya. ${ }^{26}$ Firman Allah swt.dalam Q.S. Ibrahim [14] : 4 yang terjemahannya sebagai berikut:

"Kami tidak mengutus seorang rasulpun, melainkan dengan bahasa kaumnya, supaya ia dapat memberi penjelasan dengan terang kepada mereka. Maka Allah menyesatkan siapa yang Dia kehendaki, dan memberi petunjuk kepada siapa yang Dia kehendaki. dan Dia-lah Tuhan yang Maha Kuasa lagi Maha Bijaksana." 27

\section{Kinerja Karyawan}

a. Pengertian Kinerja

Kinerja dapat dipandang sebagai proses maupun hasil pekerjaan. Kinerja

\footnotetext{
26Veithzal Rivai, dkk, Pemimpin, 62.

27Kementrian Agama RI, Al-Qur'an dan Terjemahan, 256.
}

merupakan suatu proses tentang bagaimana pekerjaan berlangsung untuk mencapai hasil kerja. Namun hasil pekerjaan itu sendiri juga menunjukan kinerja. ${ }^{28}$

Menurut Kasmir kinerja merupakan hasil kerja yang telah dicapai dalam menyelesaikan tugastugas dan tanggung jawab yang diberikan dalam suatau periode tertentu. ${ }^{29}$

b. Indikator Kinerja

Terdapat tujuh indikator kinerja. Dua diantaranya mempunyai peran sangat penting, yaitu tujuan dan motif.

Kinerja ditentukan oleh tujuan yang hendak dicapai dan untuk melakukannya diperlukannya adanya motif. Tanpa dorongan motif untuk mencapai tujuan, kinerja tidak akan berjalan. Dengan demikian, tujuan dan motif menjadi indikator utama dari kinerja.

Namun, kinerja memerlukan adanya dukungan sarana, kompetensi, peluang, standar, dan umpan balik. Kaitan di antara tujuh indikator tersebut digambarkan oleh Hersey, Blanchard, dan Johnson dengan penjelasan seperti berikut. ${ }^{30}$

1) Tujuan

Tujuan merupakan keadaan yang berbeda yang secara aktif dicari oleh seorang individu atau organisasi untuk dicapai. Pengertian tersebut mengandung makna bahwa tujuan bukanlah merupakan persyaratan, juga bukan merupakan sebuah keinginan.

\footnotetext{
${ }^{28}$ Wibowo, Manajemen, 81.

${ }^{29}$ Kasmir, Manajemen Sumber Daya Manusia, (Jakarta : Rajawali Pers, 2016), 182.

${ }^{30}$ Wibowo, Manajemen Kinerja (Jakarta: PT RajaGrafindo Persada, 2010), 78.
}

e-ISSN: 2686-6625 


\section{Jurnal Ilmu Perbankan dan Keuangan Syariah Vol. 1 No. 2 Tahun 2020}

Tujuan merupakan sesuatu keadaan yang lebih baik yang ingin dicapai di masa yang akan datang. Dengan demikian, tujuan menunjukan arah ke mana kinerja harus dilakukan. Atas dasar arah tersebut, dilakukan kinerja untuk mencapai tujuan. Untuk mencapai tujuan, diperlukan kinerja individu, kelompok, dan organisasi. Kinerja individu maupun organisasi berhasil apabila dapat mencapai tujuan yang diinginkan.

\section{2) Standar}

Standar mempunyai arti penting karena memberitahukan kapan suatu tujuan dapat diselesaikan. Standar merupakan suatu ukuran apakah tujuan yang diinginkan dapat dicapai. Tanpa standar tidak dapat diketahui kapan suatu tujuan tercapai.

Standar menjawab pertanyaan tentang kapan kita tahu bahwa kita sukses atau gagal. Kinerja seseorang dikatakan berhasil apabila mampu mencapai standar yang ditentukan atau disepakati bersama antara atasan dan bawahan.

3) Umpan Balik

Antara tujuan, standar, dan umpan balik bersifat saling terkait. Umpan balik melaporkan kemajuan, baik kualitas maupun kuantitas, dalam mencapai tujuan yang didefinisikan oleh standar. Umpan balik terutama penting ketika kita mempertimbangkan "real goals" atau tujuan sebenarnya. Tujun yang dapat diterima oleh pekerja adalah tujuan yang berkna dan berharga.

Umpan balik merupakan masukan yang dipergunakan untuk mengukur kemajuan kinerja, standar kinerja, dan pencapaian tujuan. Dengan umpan balik dilakukan evaluasi terhadap kinerja dan sebagai hasilnya dapat dilakukan perbaikan kinerja.

4) Alat atau Sarana

Alat atau sarana adalah sumber daya yang dapat dipergunakan untuk membantu menyelesaikan tujuan dengan sukses. Alat atau sarana merupakan faktor penunjang untuk pencapaian tujuan. Tanpa alat atau sarana, tugas pekerjaan spesifik tidak dapat dilakukan dan tujuan tidak dapat diselesaikan sebagaimana seharusnya. Tanpa alat tidak mungkin dapat melakukan pekerjaan.

5) Kompetensi

Kompetensi

merupakan persyaratan utama dalam kinerja. Kompetensi merupakan kemampuan yang dimiliki oleh seseorang untuk menjalankan pekerjaan yang diberikan kepadanya dengan baik. Orang harus melakukan lebih baik sekedar belajar tentang sesuatu, orang harus dapat melakukan pekerjaannya dengan baik. Kompetensi memungkinkan seseorang mewujudkan tugas yang berkaitan dengan pekerjaan yang diperlukan untuk mencapai tujuan.

6) Motif

Motif merupakan alasan atau pendorong bagi seseorang untuk melakukan sesuatu. Manajer memfasilitasi motivasi karyawannya dengan insentif berupa uang, memberikan pengakuan, menetapkan tujuan menantang, menetapkan standar terjangkau, menerima umpan balik, memberikan kebebasan melakukan pekerjaan termaksut waktu melakukan pekerjaan, menyediakan sumber daya yang diperlukan dan menghapuskan tindakan yang mengakibatkan disintensif. 


\section{Jurnal Ilmu Perbankan dan Keuangan Syariah Vol. 1 No. 2 Tahun 2020}

7) Peluang

Pekerjaan perlu mendapatkan kesempatan untuk menunjukan prestasi kerjanya. Terdapat dua faktor yang menyumbangkan pada adanya kekurangan kesempatan untuk berprestasi, yaitu kesediaan waktu dan kemampuan untuk memenuhi syarat.

Tugas mendapatkan prioritas lebih tinggi, mendapatkan perhatian lebih banyak, dan mengambil waktu yang tersedia. Jika pekerja dihindari karena supervisor tidak percaya terhadap kualitas atau kepuasan konsumen, mereka secara efektif akan dihambat dari kemampuan memenuhi syarat untuk berprestasi. ${ }^{31}$

\section{METODE PENELITIAN}

Pendekatan yang digunakan dalam penelitian ini adalah pendekatan kuantitaif, karena penelitian ini terfokus untuk mengetahui pengaruh gaya kepemimpinan dan motivasi kerja terhadap kinerja karyawan. Penelitian ini dilakukan di Bank Mandiri KCP Palu Imam Bonjol.

Peneliti memberikan questioner kepada 48 respondent nasabah Bank Mandiri. Quesioner menggunakan lima skala likert .

Teknik analisis data yang digunakan dalam penelitian ini adalah analisis kuantitaif, yaitu proses analisis terhadap data-data yang berbentuk angka dengan cara perhitungan secara statistik untuk mengukur kualitas produk dan desain terhadap keputusan pembelian produk gadai emas. Analisa

\footnotetext{
${ }^{31}$ Ibid., 80.
}

data dilakukan melalui tahap uni validitas, reabilitas, uji regresi berganda, dan uji asumsi klasik. Untuk oembuktian hipotesis penulis menggunakan uji f dan uji t. ${ }^{32}$

\section{HASIL DAN PEMBAHASAN}

\subsection{Deskripsi Umum Subjek Penelitian}

\section{Kesimpulan}

Berdasarkan hasil penelitian pada bab IV dapat disimpulkan bahwa secara Parsial variabel Gaya Kepemimpinan (X1) mempunyai pengaruh Signifikan terhadap Kinerja Karyawan (Y) pada Bank Mandiri KCP Palu Imam Bonjol, dengan besaran Gaya Kepemimpinan 56\%. Secara Parsial variabel Motivasi Kerja (X2) mempunyai pengaruh namun tidak Signifikan terhadap Kinerja Karyawan (Y) pada Bank Mandiri KCP Palu Imam Bonjol, dengan besaran Gaya Kepemimpinan $13,5 \%$.

Adapun Secara serempak atau simultan variabel Gaya Kepemimpinan (X1) dan Motivasi Kerja (X2) mempunyai pengaruh Signifikan terhadap Kinerja Karyawan (Y) pada Bank Mandiri KCP Palu Imam Bonjol. Dimana besaran pengaruh dapat dilihat pada table model summary pada kolom adjusted $R$ square yaitu sebesar $41,1 \%$.

\section{Daftar Pustaka}

${ }^{32}$ Nurdin, N., \& Mir'atun, M. a. (2018). Do Government And Private Sharia Commercial Banks Practice Similar Financial Social Responsibility Disclosure. Hunafa: Jurnal Studia Islamika, 15(2), 285-321. 


\section{Jurnal Ilmu Perbankan dan Keuangan Syariah \\ Vol. 1 No. 2 Tahun 2020}

Ghozali, Imam. Aplikasi Analisi Nultivariate Dengan Program IBM SPSS 21. Cet. VII; Semarang: Badan Penerbit UNDIP, 2013.

Ghozali, Imam. Aplikasi Analisis Multivariate Dengan Program IBM SPSS 21, Edisi ketujuh. Semareng: Badan Penerbit Universitas Diponegoro, 2013.

Hasibuan, Malayu. Manajemen Sumber Daya Manusia. Edisi Revisi. Jakarta : Bumi aksara, 2012.

Indrawan, Rully dan Popy Yaniawati. Metode Penelitian. cet.I; Bandung: PT. Rafika Aditama, 2014.

Kasmir. Manajemen Sumber Daya Manusia. Jakarta : Rajawali Pers, 2016.

Mangkunegara, A.Anwar Prabu. Manajemen Sumber Daya Manusia Perusahaan. Bandung: PT. Remaja Rosdakarya, 2011.

Martoyo, Susilo. Manjemen Sumber Daya Manusia. Yogyakarta : BPFEYogyakarta, 2000.

Riduan. Penelitian Untuk Guru, Karyawan dan Penelitian Pemula. Bandung: ALFABETA 2012.

Riduan, dkk. Cara Mudah Belajar SPSS 17.0 dan Aplikasi Statistik Penelitian. Cet, III, Bandung: ALFABETA, 2013.

Rivai, Veithzal, dkk. Pemimpin dan Kepemimpinan dalam Organisasi. Jakarta: Rajawali Pers, 2014.

Sarjono, Haryadi dan Wilda Julianti, SPSS vs LISREL Sebuah Pengantar, Aplikasi Untuk Riset. Jakarta: Salemba Empat, 2011.
Sugiono. Metode Penelitian Kuantitatif Kualitatif dan RED. Bandung: Alfabeta, 2013

Sugiyono. Metode Penelitian Adminitrasi, (Bandung: ALFABETA, 2011)

Supardi. Metode Penelitian Ekonomi dan Bisnisi. Yogyakarta: UII Perss, 2005.

Wibowo. Manajemen Kinerja. Jakarta: Rajawali Pers, 2012.

-----. Manajemen Kinerja. Jakarta: PT RajaGrafindo Persada, 2010.

-----. Perilaku Dalam Organisasi. Jakarta: PT RajaGrafindo Persada, 2016.

-----. Perilaku Dalam Organisasi. Jakarta: Rajawali Pers, 2016.

Gusli, "Pengaruh Gaya Kepemimpinan dan Motivasi Kerja Terhadap Kinerja Karyawan Pada PT. PLN (Persero) Rayon Makassar Selatan", Skripsi (Makassar: UIN Alauddin Makassar, 2016). http:/ / repositori.uinalauddin.ac.id, diakses 29 Januari 2019.

Iskandar, Yogi. Pengaruh Kesesuaian Kompensasi terhadap Kinerja Karyawan pada PT. Bentoel Distribusi Utama Cabang Palu (Skripsi IAIN Palu).

Nugroho, Rakhmat. "Analisis Fakto-faktor Yang Mempengaruhi Kinerja Karyawan (Studi Empiris pada PT. Bank Tabungan Negara (Persero), Cabang Bandung)", Tesis (Semarang: Universitas Diponegoro Semarang, 2006). http://core.ac.uk, diakses 9 Januari 2019.

Nurdin, N. (2018). Institutional Arrangements in E-Government Implementation and Use: A Case Study From Indonesian Local 


\section{Jurnal Ilmu Perbankan dan Keuangan Syariah \\ Vol. 1 No. 2 Tahun 2020}

Government. International Journal of Electronic Government Research (IJEGR), 14(2), 44-63. https:/ / doi.org/10.4018/ijegr.201 8040104

Nurdin, N., Stockdale, R., \& Scheepers, H. (2012). Internal Organizational Factors Influencing Sustainable Implementation of Information Systems : Experiences from a Local Government in Indonesia Australasian Conference on Information Systems (ACIS) 2012, Deakin University, Geelong, Victoria, Australia. http://dro.deakin.edu.au/view/ DU:30049058

Nurdin, N., Stockdale, R., \& Scheepers, H. (2014). Coordination and Cooperation in E-Government: An Indonesian Local EGovernment Case The Electronic Journal of Information Systems in developing Countries, 61(3), 1-21.

Nurdin, N., \& Yusuf, K. (2020). Knowledge management lifecycle in Islamic bank: the case of syariah banks in Indonesia. International Journal of Knowledge Management Studies, 11(1), 59-80. https:/ / doi.org/10.1504/ijkms.20 20.105073

Reza, Regina Aditya, "Pengaruh Gaya Kepemimpinan, Motivasi dan Disiplin Kerja Terhadap Kinerja Karyawan PT. Sinar Santosa Perkasa Banjarnegara". Skripsi (Fakultas Ekonomi, Universitas Diponegoro, 2010).

http://eprints.undip.ac.id, diakses 8 Januari 2019.

Tampi, Bryan Johannes. "Pengaruh Gaya Kepemimpinan dan Motivasi Terhadap Kinerja Karyawan pada PT. Bank Negara Indonesia, TBK (Regional Sales Manado). http://www.academia.edu, diakses 6 Januari 2019.

Sakinah, Pengaruh Bauran Pemasaran Keputusan Membeli Kartu Prabayar Produk Telkomsel Pada Mahasiswa IAIN Palu, Skripsi (Palu: IAIN 2014). 